臨床

トロトラスト注入後に発症した赤白血病の 1 例

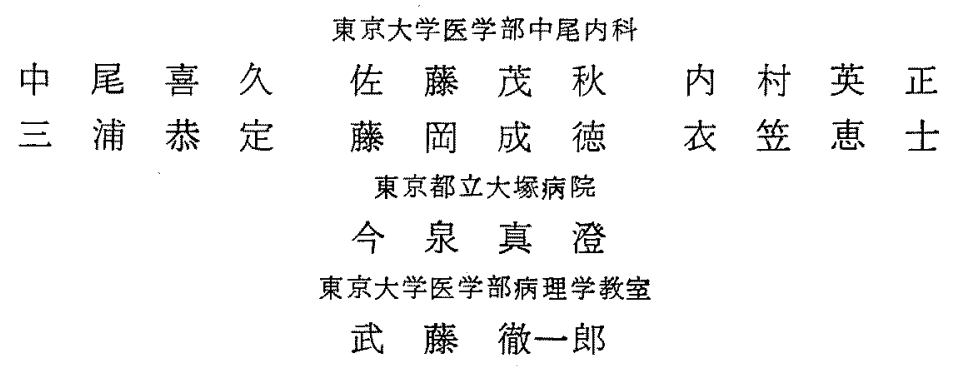

\title{
A CASE OF ERYTHROLEUKEMIA DEVELOPED AFTER THOROTRAST INJECTION.
}

Kiku Nakao, Shigeaki Sato, Hidemasa Uchimura, Yasusada Mrura, Seitoku Fujroka and Keiji Kinugasa

The Third Department of Internal Medicine, Faculty of Medicine, University of Takyo

Masumi ImaIzumi

Department of Internal Medicine, Metropolitan Otsuka Hospital

Tetsuichiro Muto

Department of Pathology, Faculty of Medicine,

University of Tokyo

\begin{abstract}
概要 トロトラストによる遅発障害は，肝硬変・胆管癌など，肝を中心としたものがかなり報告され ているが，血液疾患を来たした例は少ない，われわれはトロトラスト注入後22年目に発症したと思わ れる赤白血病の症例を経験したので報告する，症例は59才男で，昭和19年に左大腿動脈よりトロトラ ストによると思われる血管造影術を受け，昭和 39 年ころよりパーキンソン症候群が出現し，41年当科 を訪れて高度の貧血と後に末梢血中に幼若細胞を発見され，骨轲所見などから臨床的に赤白血病と診 断され，同時に腹部 $\mathrm{X}$ 線像で異常陰影があり，ヒューマンカウンター，オートラジオグラフィーでト ロトラスト沈着が確認された。剖検でも脾・リンパ節・骨髄・肝にトロトラスト沈着が発見され血液 細胞の異型性, 各臓器への細胞浸潤などから病理学的にも赤白血病と猃断され，放射能を持つトロト ラストと赤白血病発症との関係が問題となつた。
\end{abstract}

\section{緒言}

トロトラストによる達発障害はわが国见拈いて もかなりの報告例があるが，その大部分は外国の 例之同じく，胆管癌・肝硬変など，肝臓を中心と 昭和 42 年 3 月11日 第 183 回関東地方会推鵲
したもので血液疾患をきたした例は少ない，最近 われわれはトロトラスト注入後, 約 20 年にして発 症した赤白血病の症例を経験し，剖検する機会を 亲たのでここに報告し，さらに文献例について も検討を加吝てみた。 


\section{症例}

患者：51才, 男, 商業.

主訴：歩行障害, 貧血.

家族歴：特記すべきことなし．

既往歴：昭和19年10月, 陸軍病院で痔核の摘 除を受けそその後左下肢の腫脹を来たしたため， 左大腿動脈より血管造影術を受けている。

現病歴： 昭和39年ころより全身の動作がにぶ くなり，歩行障害を来たすようになつたので，某 病院を訪れ，脳血管障害といわれたが，当時は貧 血, 血液像の異常は認められなかつた。

昭和41年になり歩行障害が増強し, 疲労性, 手 振顫が出現し, 当科外来を訪れて, パーキンソン 症候群と診断された。 またこれと同時に高度の貧 血を発見され，一たん都立大塚病院へ入院し，約

1,000 mlの輸血を受けた。パーキンソン症候群は 塩酸 プロサイクリジン，5-クロロベンゾキサゾ リノンなどの投与を受けてやや軽快したが，末梢 血中に, 赤芽球, 骨髄芽球などの幼若細胞つ出現 をみたので精査のため, 昭和 41 年 8 月 23 日当科へ 転院した。

入院時理学的所見：意識は清で, 脈拍76, 整，血圧 132/62, 顔貌はやや表情に乏しかつた。 眼䀫結膜の貧血は高度だが黄疸はなく, 眼底に軽 度の動脈硬化がみられた。心尖部・大動脈弁口部 に強度 II 度の収縮期雑音があり，腹部では肝が右 下胁に 2 横指触知され, 辺縁はまるく, 表面は平 滑, 軟で圧痛はなかつた。脾・表在リンパ節は触 知されなかつた．左単径部には血管造影術を受け た際の癉痕があつた。神経学的には, かれ声, 言 語緩徐, 小股で動摇性の歩行, 手振顫, 筋硬直な どのパーキンソン症候群があつたが，筋力および 腱反射は正常であつた。

検查所見： 赤沈 $45 \mathrm{~mm}$ ( 1 時間), 血算 へモグ ロビン $3.8 \mathrm{~g} / \mathrm{dl}$, 赤血球数 $159 \times 10^{4}$, ヘマトク リット $22 \%$, 血小板数 $1.0 \times 10^{4}$, 網赤血球数 $5 \%$, 白血球数 2,300 (骨髄芽球 $2.5 \%$, 骨䯣球 8.0 , 傜骨䯣球 11.0 , 桿状球 8.0 , 分葉球 13.0 , 好酸球 5.5 , リンパ球 30.0$)$, 赤芽球数 $35 / 200 \mathrm{~W}$, 出血

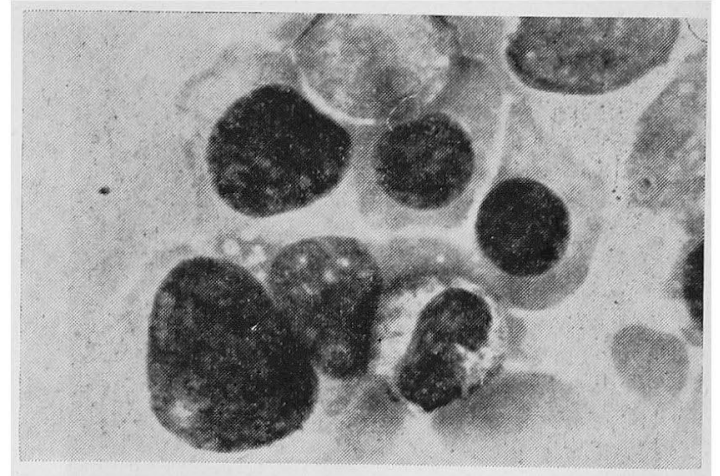

図 1。骨髄の細胞像

時間 $6^{\prime} 30^{\prime \prime}$ ，凝固時間 $8^{\prime}$ ，プロトロンビン時間 $15^{\prime \prime}(100 \%)$ ，赤血球抵抗 $0.40 \sim 0.32$ ，骨髄所 見, 細胞数 $37,500, \mathrm{G} / \mathrm{E}$ 比 0.4 , 核細胞質の 異常 の強い芽球が見られ，赤芽球では細胞質一核成熟 の解離，核分裂の異常がみられた（図1）.

屎尿，異常なし．心電図，異常なし．胸部X線 像, 異常なし. 血清反応 C R P (一), A S L O 625 , 口反応 $($ 一), クームス試験 $($ ，）, 寒冷凝集 反応 (一), 血清生化学, 総蛋白 $6.8 \mathrm{~g} / \mathrm{dl}, \mathrm{A} / \mathrm{G}$ 比 1.1 , 尿素窒素 $2.0 \mathrm{mg} / \mathrm{dl}$, クレアチニン $1.1 \mathrm{mg} / \mathrm{dl}$, クレアチン $3.4 \mathrm{mg} / \mathrm{dl}, \mathrm{Na} 136 \mathrm{mEq} / l, \mathrm{~K} 3.8 \mathrm{mEq} / l$, $\mathrm{Cl} 108 \mathrm{mEq} / \mathrm{l}, \mathrm{Ca} 8.6 \mathrm{mg} / \mathrm{dl}, \mathrm{P} 3.1 \mathrm{mg} / \mathrm{dl}$, 尿酸 5.8 $\mathrm{mg} / \mathrm{dl}$, 総コレステロール $172 \mathrm{mg} / \mathrm{dl}$.

肝機能検査, alk-P-ase 3.8Bessey単位, 黄疸指 数 6, T T T 3, ZnST11, G O T25, G P T 39, 血 清電気泳動, 総蛋白 $6.7 \mathrm{~g} / \mathrm{dl}, \quad$ alb54.1\%， $\alpha$-gl 8.5, $\beta$-gl 14.0, $\gamma$-gl 23.4, 免疫電気泳動, 異 常なし，肝ェューグラフィー，透過性やや悪し． 肝シンチグラフィー異常なし。十二指腸液, 胆 汁の排泄はやや悪いが，濃縮はよい。沈渣異常な し.

消化管X線像 異常なし. 頭蓋X線像 異常な し. 脳波 異常なし、血清セルロプラスミン, $0.8820 \mathrm{D}$ (正常值, $0.12 \sim 0.24 \mathrm{D}$ ).

腹部 $\mathrm{X}$ 線像 図 2 のごとく, 脾, 大動脈周囲な いし肝門部に相当する部位にそれぞれ網状および 播種状の異常陰影がみられた。

骨盤部 X線像 ; 左単径部の血管造影術を受けた 


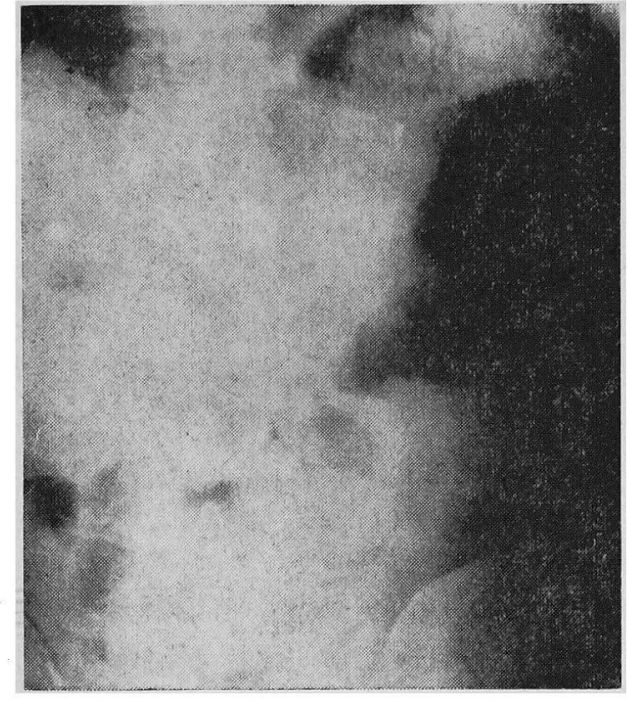

図 2, 腹部X線写真

部位に異常陰影があつた。

以上，腹部扣よび骨盤部 $\mathbf{X}$ 線像の所見からトロ トラストなどの造影剂の沈着が考えられたので， 病歴をよく問い正してみたところ，前記のように 22年前, 血管造影術を受けていることがわかつ た、そこでヒューマンカウンターで体内の放射能 の測定をしたところ，図 3 (A) のごとく，剣状 突起の高さにピークを持つ $\gamma$ 線が検出され，さら にこれを波高分析してみると，図 3 （B）のよう に，トリウム，アクチニウム，ビスマスなどのト リウムの 崩壊系列に一致する各ピークが方られ た、な招この図で198Auに一致するピークがみら れるのは; 肝シンチグラフィーを行なつた時注入 した金コロイドの放射能が消失せず残つていたた めであり，図3（A）では ${ }^{198} \mathrm{Au} の 0.412 \mathrm{MeV}$ の $\gamma$ 線はカットして測定している。

また，胸骨骨髄の生検組織標本でオートラジオ グラフィーを行なつたところ，図 4 のごとくの $\alpha$ トラックが多数認められ，ヒニーマンカウンター の所見とともに，トロトラストが体内に沈着して いることを証明する手がかりとなつた。

入院後経過：入院時あつた高度の貧血は， 新鮮血約 $2,000 \mathrm{ml}$ の 輸血によりへモグロビン值
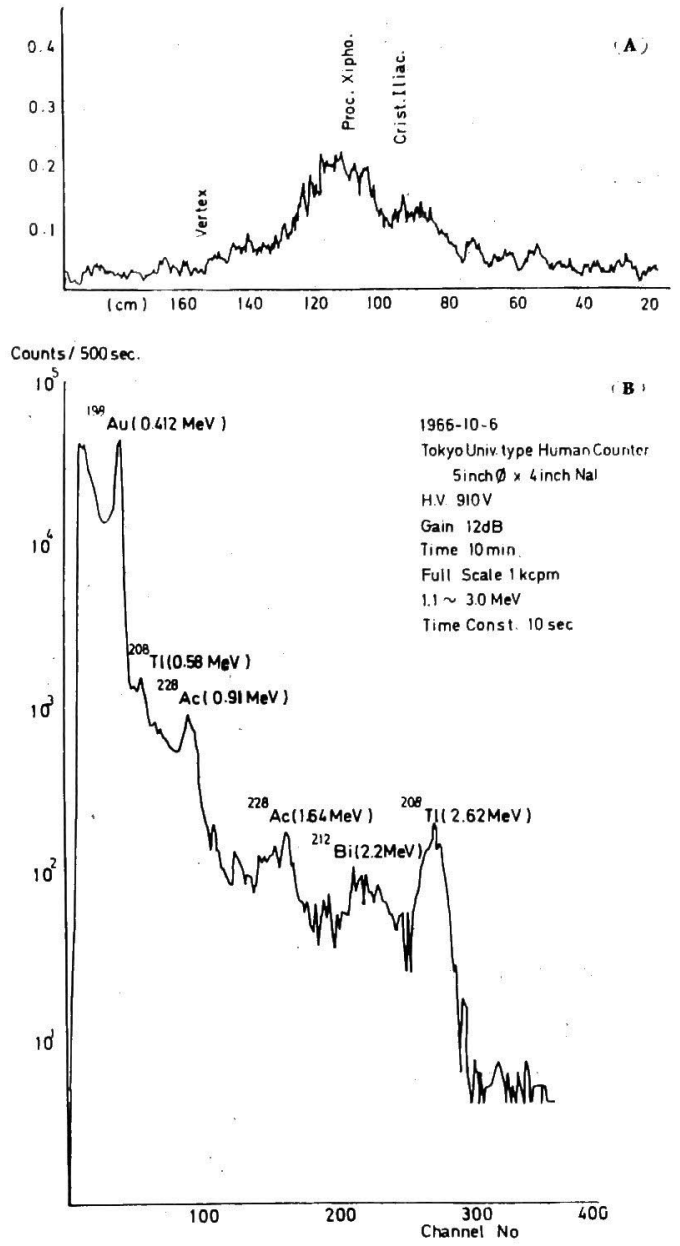

因 3. (A)Human counterによるLinear scanning (B) $\gamma$ 線の波高分析

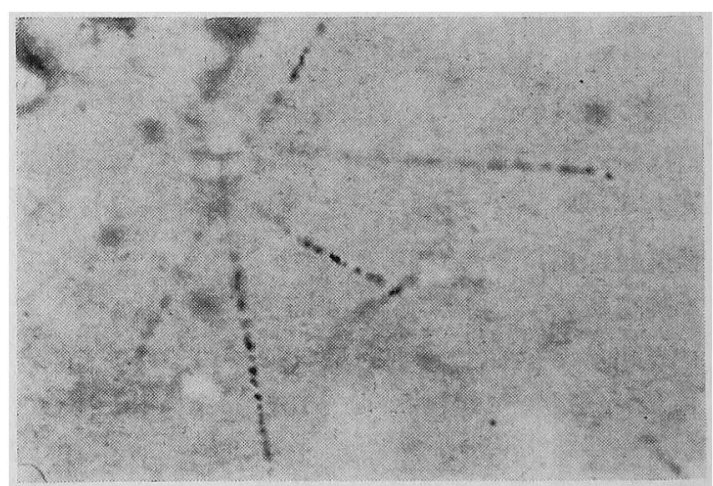

図 4.胸骨骨髄標本のオートラジオグラフィーで 見られた $\alpha$ track 
$10.3 \mathrm{~g} / \mathrm{dl}$ にで回復したが, 白血球数特よび血液 像はほとんど変化なく血小板数は徐々に減少 し, 1 カ月後には出血傾向が出現し, 貧血が再び 高度となつてきた。 またこのころより発熱と黄疸 が出現し, alk-P-ase14.0, G O T60, G P T 126 と 上昇し，B S P も25\%と高值であつた。この時の 胸部X線像では右肺上葉に肺炎様陰影がみられ, 抗生物質を投与したところ，一時下熱し，肺陰影 も消失し黄㾝は軽度となつた。しかし入院後約50 日目ころより再び発熱と黄疸が出現し, GOT 294, G P T 360と上昇, 60 日目ころには吐血 下血が出現し，10月31日入院後70日で死亡した．

剖検所見： 全身的に黄疸が強く, 皮膚には点 状出血があつた。臓器別にみると, 肉眼的には, 脾および肝の表面扣よび割面で点ないし線状の白 色の沈着物がみられた．図 5 は脾のX線像である が，腹部X線像でみられたよらなトロトラストと 思われる点状陰影がみられる。

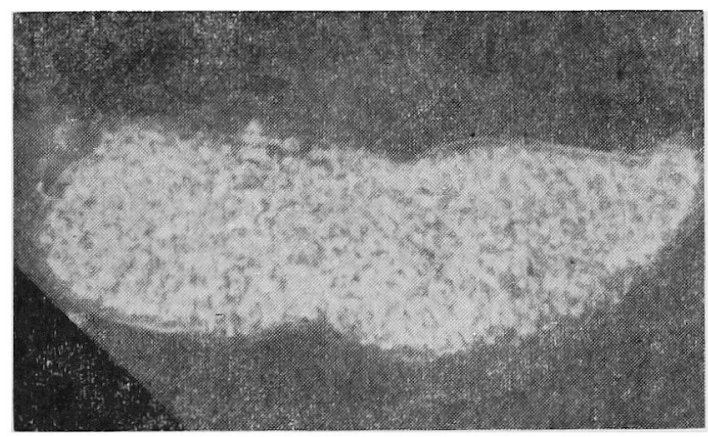

因 5 , 脾 X線写真

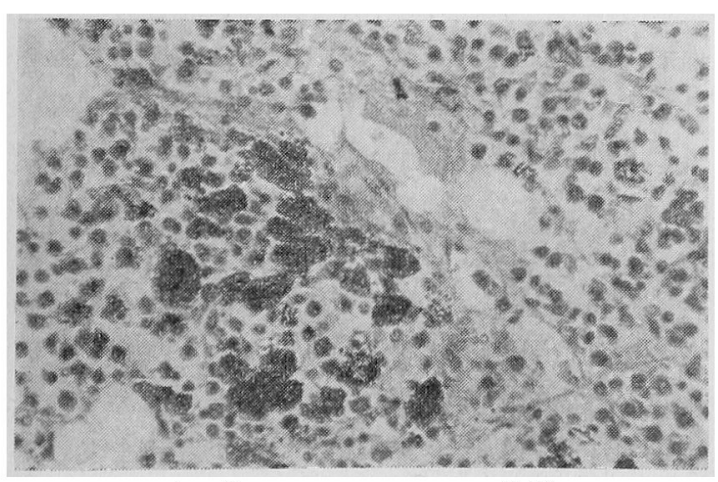

図6.脾へのトロトラストの沈着.
組織学的にも脾の細網細胞および脾, 肝梁のグ リソン氏鞘および座状細胞, 肝門および後腹膜り ソパ節の細網細胞扣よび骨髄の細網細胞にトロト ラストの沈着がみられた（図6）.

骨髄は赤色髄で，骨髄系細胞・巨細胞様赤芽球 および異常な巨核球の增殖があり, 腎・脾・リン パ節拉よび肝には骨髄系ならびに赤芽球系細胞の 白血病性浸潤がみられた。また脾は55 g と菱縮し ていて，全身的にリンパ節の腫脹はみられなかつ た，脳の検索は拒否され開頭しえなかつた。

この他に出血性化膿性胆霊炎・出血性線維素性 化膿性心外膜炎 - 壊死性食道咽頭炎・腎皮質の多 発性膿瘍などの敗血症の所見がみられ, 肺には出 血と浮腫拉よび右上葉つ膿瘍がみられた。

肝は $1,750 \mathrm{~g}$ と肥大し, 胆汁色素の沈着 が強 く, 中心壊死および門脈周团の線維化が認められ たが，腫瘍・肝硬変は認められなかつた。

その他, 消化管·気道・尿路に出血があり, $200 \mathrm{ml}$ 程の血性の腹水も認められた。

臟器別放射能測定結果 : 剖検後, 各臓器を湿 重量 $1 \mathrm{~g}$ ずつとり, ポリエチレンチューブにつめ てウェルタイプのンンチレーションカウンターで $\gamma$ 線を測定してみると, 各蔵器 $1 \mathrm{~g}$ 当り, 1 分 間のカウント数は, 脾 2,763 , 肝門部リンパ節 1，164，骨髄 198，骨皮質 145，肝 127 となり， 明らかな放射能が検出された。これに対し，肺 心・腎、膵などには放射能はほとんど認められな かつた。 また, 念のため, 比色法にてトリウムの 化学的測定を各蔵器について行なつたところ, 脾 ・骨髄などでトリウムが検出された．

\section{考察}

この症例は, 貧血 血小板減少, 末梢血中への 骨髄系幼若細胞拉よび赤芽球の出現があり，骨䯣 でも, 異型性の強い骨髄系・赤芽球系幼若細胞の 増殖があり,さら肝・脾腎・リンパ節などへ の骨咀系・赤芽球系細胞の浸潤があることから赤 白血病之診断された。 また同時に，22年前に受け た血管造影術がトロトラストによるものであり， それが脾 リンパ節・骨・肝臓に沈着しているこ 
とも確認された。

トロトラストは $20 \%$ 二酸化トリウム $\left(\mathrm{ThO}_{2}\right)$ と保護コロイドとして20\%ブドウ糖または16〜 19\%のデキストラン，さらに防腐剤として0.15\% のmethyl-p-hydroxybenzolを含む造影剤で，1928 年, Blühbaum ${ }^{11}$ が気管支造影に 使用してから， 血管造影，腎昷造影，肝脾造影などにすぐれた造 影剂として各国で広く利用されていた。しかし， このコロイドは一たん体内にとり込まれると，肝 ・脾リンパ節・骨髄などの細網内皮系などに 沈着し，長期間にわたつて排泄されないで残る。 また製作時含 れている ${ }^{282} \mathrm{Th}$ と $^{228} \mathrm{Th}$ 半減期

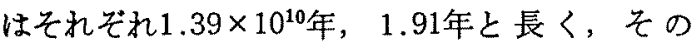
崩壊系列の放射能は $\alpha$ 線 $90 \% ， \beta$ 線 $9 \% ， \gamma$ 線 $1 \%$ といわれ，とくに $\alpha$ 線は，組織透過力は30〜 $50 \mu$ とさいが，そのイオン化エネルギーが大で あるため，沈着臓器におよぼす傷害的影響が大さ 々，放射能による種々の遅発障害を来たし，1947 年ころにはトロトラストの使用は中止された。こ の遅発障害は，1942年Wohlwill22が急性白血病つ 症例を報告したのが初めであつたが，1947年には Mac Mahonが肝肉腫の症例を報告し，以来かな りの多くの報告例がある。わが国では発癌症例之 しては1956年, 当教室の中尾ら ${ }^{3)}$ が胆管癌の症例 を報告したつが初めであるが，その後同様の遅発 障害の報告例が堌光，1963年には，矢数ら") は国 内で43例，国外では53例の報告があつたとしてい る．最近これらの報告例数は增えて括り，1966 年，上田 ${ }^{5)}$ は国内で約70例の報告例を集めてい る。これら荤発障害の内容は，外国の例も含め て，胆管癌・肝硬変または肝線維症など，肝を 中心としたものが多く，他の臓器の悪性腫瘍を来 たしたものも若千あるが，血液疾患を来たした例 は少なく，わが国では数例の報告があるにすぎな W

本例に拈いてトロトラストが赤白血病の原因と なつているか否かは議論のあるところであるが， 1965年，ポルトガルのHorta ${ }^{8)} ら の$ 報告がこのこと になんらかの示唆を与えるすのと思われる。ここ
では1930年から1950年の間にリスボン大学の脳神 経外科を中心にしてトロトラストによる造影術を 受けた 2,377名のうち，経過を観察できた 1,207 名について，どの上うな遅発障害が発生したかを 報告しているが，らち42例に肝線維症，81例に局 所の肉芽腫，3例にその周囲の悪性腫瘍，22例 に肝・脾などの血管内皮腫, さらに22例に, 気 管支・胃・啹頭 胆道などの葴器の癌の発生をみ ているが，注目すべきことは16例に血液疾患を来 たしたといつている。この内訳は急性骨䯣性白血 病 5 例, 急性単球性白血病 1 例, これは同時に赤 芽球系の增殖も伴なつていた，さらに慢性骨䯣性 白血病 2 例, 再生不良性貧血 6 例, 紫斑病 2 例之 なつており，トロトラストの注入法は大部分が脳 血管を中心上した血管造影術であるが，中に，肝 脾造影術を受けたものもいた。また注入量は $20 \mathrm{ml}$ から60mlで，血液疾患の発症までには 2 年または 7 年と短いものもあるが，大部分は17年から 25 年 が経過している．また，この白血病の発生率は一 般人口を対照とするよりはるかに大きい

その他これまでに報告されたいくつかのトロト ラストによる血液疾患を集めてみると，さきに述 ベた1942年のWohlwillの急性白血病の症例をは じめ，1947年にはSpierらが再生不良性貧血，1953 年にMoeschlinらがPanmyelopathieとして報告し た例，1954年のGrebeの骨髄性白血病，1956年の Looney 5のchronic lymphadenosis,1957年のNetousekらのchronic myelosis, 1966年のGausらのtoxische Thrombopenie, Osteosklerose, 急性骨䯣性白 血病の 3 例，さらにBernard ら 7 の急性前骨髄球 性白血病などがある。このBernardらの例に捻い ては，死後作製した肝・脾・骨䯣などの標本で， オートラジオグラフィーにより本例と同様に $\alpha$ ト ラックが検出されている，日本に扣いては，今 井 ${ }^{8)}$ が報告した38才の男で，17年前にトロトラ スト注入を受け，急性骨髄性白血病を来たした症 例，また横浜市大病理でみつかつた47才の男で， 23年前に盿窩動脈よりトロトラスト注入を受け， 急性骨髄性白血病を発症して死亡した例，さらに 
田中，森らによつて報告されたトロトラスト注入 を受けて死亡した26名中の 1 人が白血病であつた といら例の 3 例ほどが報告されている．日本の例 あ含め，これまで報告された血液疾患をみると， その発症までにトロトラスト注入後大部分が17年 から23年が経過しているところはHortaらの例と よく似ていて興味深いまたここれでトロトラ ス卜注入例の末梢血中の白血球に括いて染色体異 常を来たしたといら報告910)があるが，本例に打 いては骨䯣の白血球材料より行なつた染色体分析 では異常は認められなからた。

本例において妨，リンパ節・骨䯣 肝など へのトロスラストの沈着が著しいこと,トロトラ スト注入後他の症例と同じく22年の経過を経て発 症していること，さらにこれまでの報告例でトロ トラスト注入患者の白血病発生率が高いことなど を考えると，赤白血病の発生にトロトラストがな
んらかの役割をはたしていることがらかがわれ， 広く放射能による白血病発生の機序解明の上に示 唆を与えるものと思われる.なお，パーキンソン 症候群とトロトラスト注射との因果関係を剖検に よつて明確になしえなかつたことが惜しまれる。 ヒニーマンカウンターおよび $\gamma$ 線分析をしていただ いた東大医学部放射線健康管理講座の吉沢康雄助教授 に感謝いたします。

\section{文献}

1) Blühbaum, Th. et al.: Fortschritte auf dem Gebiete der Röntgenstrahlen, $37: 18,1928$. 2) Wohlwill et al.: Schweiz. Z. allg. Path. Bact., $5: 21,1942 .-3$ ) 中尾喜久他: 最新医学. $11: 1201,1958,-4)$ 矢数侑信他 : 臨内小, 18 : $313,1963 .-5)$ 上田英雄他：内科, $17: 960,1966$. -6)Horta, J. da S. et al.: Lancet, 2 (7405), : 201, 1965. -7) Bernard, J. et al.: La presse medicale, $74: 487,1966$. - -8) 今井秀夫 : 日内会 誌, $53: 492,1964$. -9) Fisher, P. et al.: Radiation Research, 29 : 505, 1966. 一10) 熊取敏之他 : 染色体，6:9179，1965. 